\title{
THREE NEW WATER MITE SPECIES OF THE GENUS PIONA KOCH, 1842 (ACARI: HYDRACHNIDIA, PIONIDAE) FROM RUSSIA
}

\author{
Petr V. Tuzovsky
}

Papanin Institute for Biology of Inland Waters, Russian Academy of Sciences, Borok, Russia; e-mail: tuz@ibiw.yaroslavl.ru

ABSTRACT: Desciptions of three new water mites: Piona caucasica (female), P. kolymaensis (male), P. neococcinoides (male)_ are provided.

KEY WORDS: Water mites, Pionidae, Piona, new species, morphology, female, male.

DOI: 10.21684/0132-8077-2019-27-1-85-93

\section{INTRODUCTION}

Although the Russian fauna of the water mites of the genus Piona Koch, 1842 currently embraces about 30 species (Sokolow 1940; Tuzovsky 2005, 2013, 2015, 2016), it is still not sufficiently investigated. The aim of this paper is to describe three new water mite species of the genus Piona from Russia.

\section{MATERIAL AND METHODS}

The specimens were collected by the author in standing waters of the Asian and European parts of Russia. Mites were sampled with a common hand net $(250 \mu \mathrm{m}$ in size $)$. The specimens were not fixed in Koenike liquid, instead, the slides were made from the fresh material. All mites were mounted in Hoyer's medium. The type material has been deposited in the collection of the Papanin Institute for Biology of Inland Waters (Borok, Russia).

Idiosomal setae are named according to Tuzovsky (1987). Furthermore, the following abbreviations are used: $\mathrm{P}-1-5$, pedipalp segments (trochanter, femur, genu, tibia and tarsus); I-Leg-1-6, first leg, segments 1-6 (trochanter, basifemur, telofemur, genu, tibia and tarsus) i.e. I-Leg-4genu of first leg; L — length; W - width; n - number of specimens measured; all measurements are given in micrometers $(\mu \mathrm{m})$.

\section{SYSTEMATICS}

Family Pionidae Thor, 1900

Genus Piona Koch, 1842

Piona caucasica Tuzovsky sp.n.

Figs. 1-9

Type material. Holotype: female, slide 1596, Europe, Russia, North Caucasus, Krasnodar Territory, Seversk District, small pond near the Ubinskaya settlement, 20 May 1976.
Diagnosis. Female. Dorsum with two small elongate platelets; setae $F c h$ short, thick; P-2 ventral margin convex with 5 dorsal setae, P-3 with three unequal setae much shorter than dorsal margin of segment, P-4 slender, with two close located small ventral setal tubercles; genital field with two bowed plates, 16-17 acetabula with six to seven anteromedial and three to four posteromedial genital setae; I-Leg-5 with six to seven short swimming setae, IV-Leg-5 with seven long swimming setae.

Description. Idiosoma oval, integument soft and finely striated. Dorsum with small elongate platelets, ratio L/W 3.0 (Fig. 1). The number and position of idiosomal setae typical for the genus Piona. All dorsal setae thin and approximately equal in length, but setae $F c h$ (Fig. 2) shorter and thicker than others idiosomal setae. All coxal groups separated and cover about half of ventral surface (Fig. 3). Anterior coxal plates with short apodemes. Sclerites, bearing setae $H v$, free and located between anterior and posterior coxal groups on each side. Medial margin of coxal plate IV two times longer than medial margin of coxal plate III. Posterior margin of coxal plates IV forming obtuse angles, apodemes moderately developed. Gonopore and acetabular plates approximately equal in length (Fig. 4). Genital field with two bowed plates bearing 16-17 pairs of acetabula. Each genital plate one acetabula in width, embracing three acetabula located in the soft integument or touching the medial acetabular plate margin. All genital setae located on the plates, six to seven setae located anteromedially and four setae-posteromedially.

Chelicera (Fig. 5) with large basal segment and short crescent chela. Pedipalp compact (Fig. 6): P-1 with single dorsodistal seta; $\mathrm{P}-2$ ventral margin slightly convex with five dorsal setae; P-3 with 


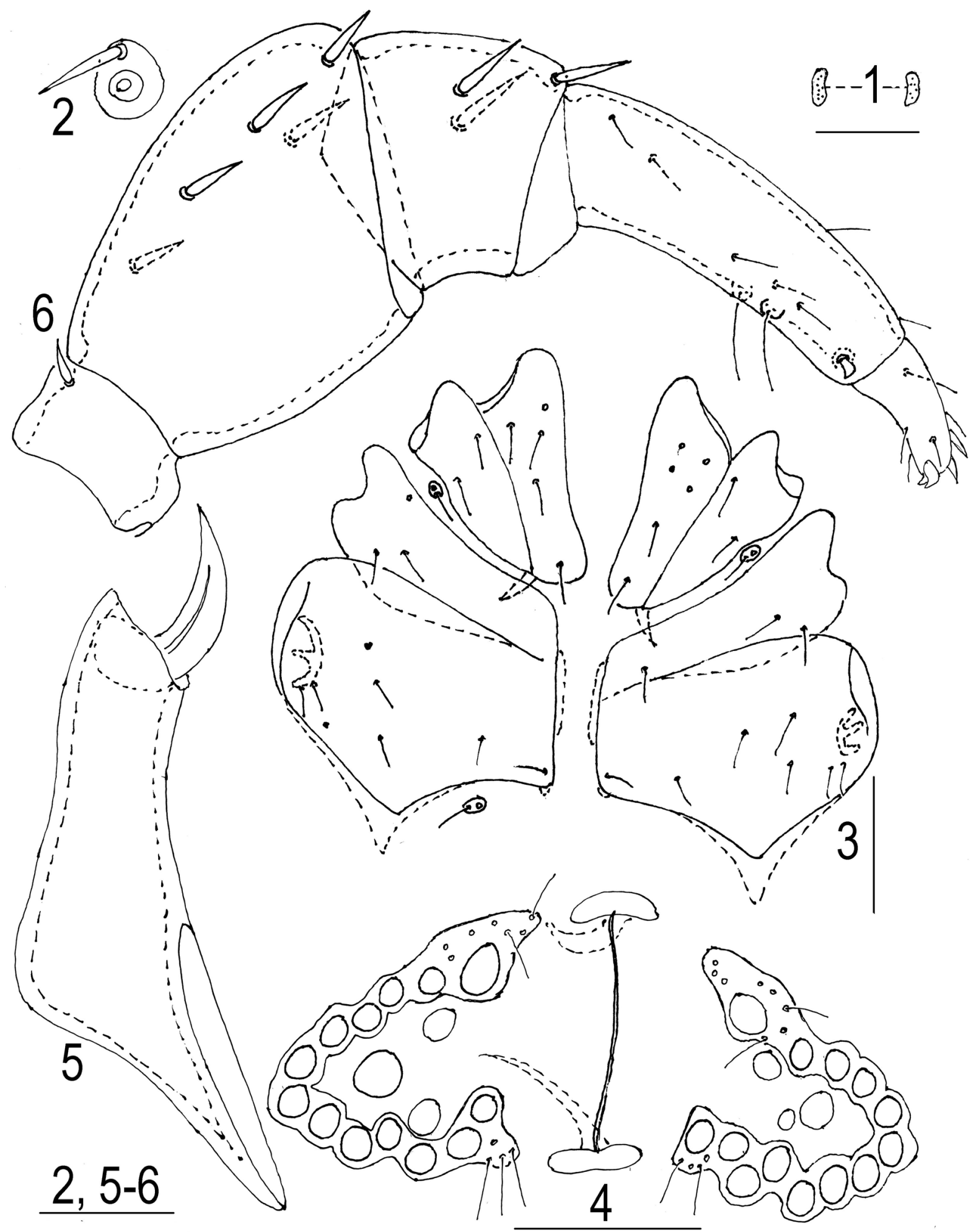

Figs. 1-6. Piona caucasica sp.n., female: 1-dorsal platelets; 2-seta Fch; 3-idiosoma, ventral view; 4-genital field; 5-chelicera; 6-pedipalp, lateral view. Scale bars: 1 and 3=200 $\mu \mathrm{m}, 4=100 \mu \mathrm{m}, 2,5-6=50 \mu \mathrm{m}$.

three short subequal setae that are located in posterior half of segment; P-4 ventral setal tubercles small and slightly separated, ventrodistal peg-like seta short; P-5 with proximal solenidion, five thin setae and four thick distal spines.
Legs thin and slender. I-Leg-4 with three to four, I-Leg-5 six to seven short swimming setae (Fig. 7). Legs II-IV with long swimming setae (Fig. 8), their number as follows: seven to eight on IILeg-4, 9-10 on II-Leg-5, seven to nine on III- 


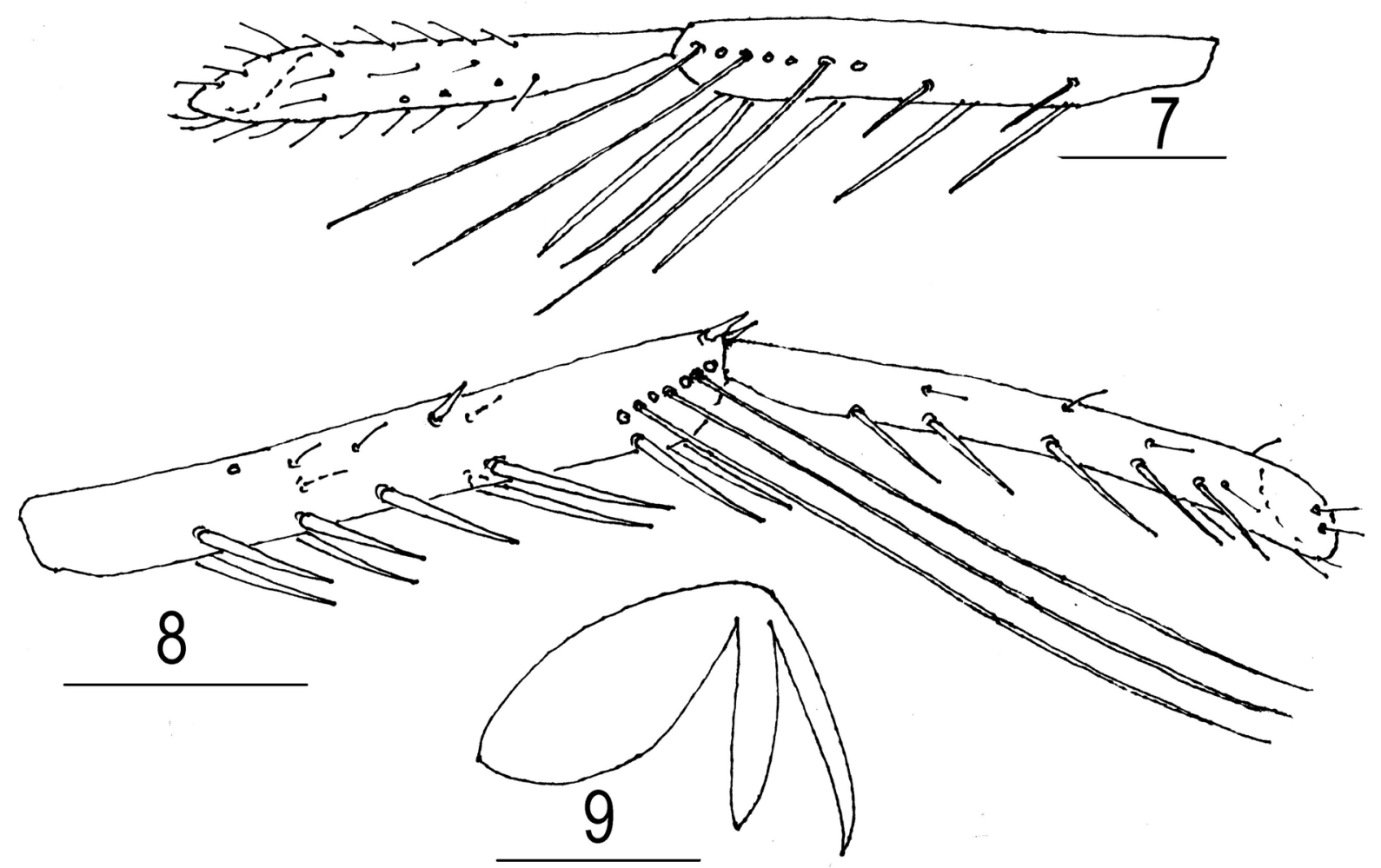

Figs. 7-9. Piona caucasica sp.n., female: 7-I-Leg-5-6; 8-IV-Leg-5-6; 9—claw of leg I. Scale bars: 7 and $8=100 \mu \mathrm{m}$, $9=50 \mu \mathrm{m}$.

Leg-4, eight to nine on III-Leg-5, five on IV-Leg-4, seven on IV-Leg-5. Claws with long, thin external clawlets and relatively short, thick internal clawlets, lamella with convex ventral margin (Fig. 9).

Measurements $(\mathrm{n}=1)$. Idiosoma L 910; dorsal plates L 55; setae Fch L 27; acetabular plates: L 140; cheliceral segments L: base 210 , chela 72 ; pedipalp segments (P-1-5) L: 36, 155, 80, 145, 42; leg segments L: I-Leg-1-6: 75,130, 160, 210, 240, 235; II-Leg-1-6: 90, 135, 185, 255, 260, 250; IIILeg-1-6: 90, 135, 185, 255, 275, 250; IV-Leg-1-6: 155, 150, 210, 275, 305, 250.

Differential diagnosis. The female of $P$. caucasica sp.n. is similar to Piona nodata (Müller, 1776), from which it is easily distinguishable by the structure of the pedipalps and setae $F c h$. Setae $F c h$ (Fig. 2 ) in the female . caucasica sp.n. short $(\mathrm{L}=27 \mu \mathrm{m})$, P-3 all setae subequal in length, distinctly shorter than dorsal margin of segment and located in posterior half of segment (Fig. 6). In contrast, in the female $P$. nodata setae $F$ ch long ( $\mathrm{L}=100-115 \mu \mathrm{m})$, P-3 lateral setae longest, equal or longer than dorsal margin of segment and located proximally or near middle of segment (Tuzovsky 2017).

Etymology. The species epithet "caucasica" is derived from the name of the territory where it was collected (Caucasus).
Habitat. Standing waters.

Distribution. Europe (Russia: North Caucasus).

\section{Piona kolymaensis sp.n.}

Figs 10-20

Type material. Holotype: male, slide 2794, Russia, Magadan Region, Yagodnoe District, small lake to the right bank of the Kolyma River, $50 \mathrm{~km}$ upstream of the Sibik-Tyellakh settlement, 10 July 1981. Paratypes: 1 male 29 June 1979 and 2 males 6 July 1981 same locality as holotype.

Diagnosis. Male. Dorsum with two comparatively broad platelets; setae $F$ ch short, thick; pedipalp slender: P-2 ventral margin straight with 8 dorsal setae, P-3 with four unequal setae, these much shorter than dorsal margin of segment, P-4 slender, with two small separate ventral setal tubercles; coxal plates IV touching, 24-30 pairs of acetabula, gonopore elongate oval, EC proximal chamber with single coil; I/II-Leg-6 distally not thickened, I-Leg-5 with 3-5 short swimming setae.

Male. Color red. Idiosoma oval, integument soft and finely striated. The number and position of idiosomal setae typical for the genus Piona. Dorsum with two small elongate (L/W ratio 2.63.0) platelets (Fig. 10). All dorsal setae thin and 


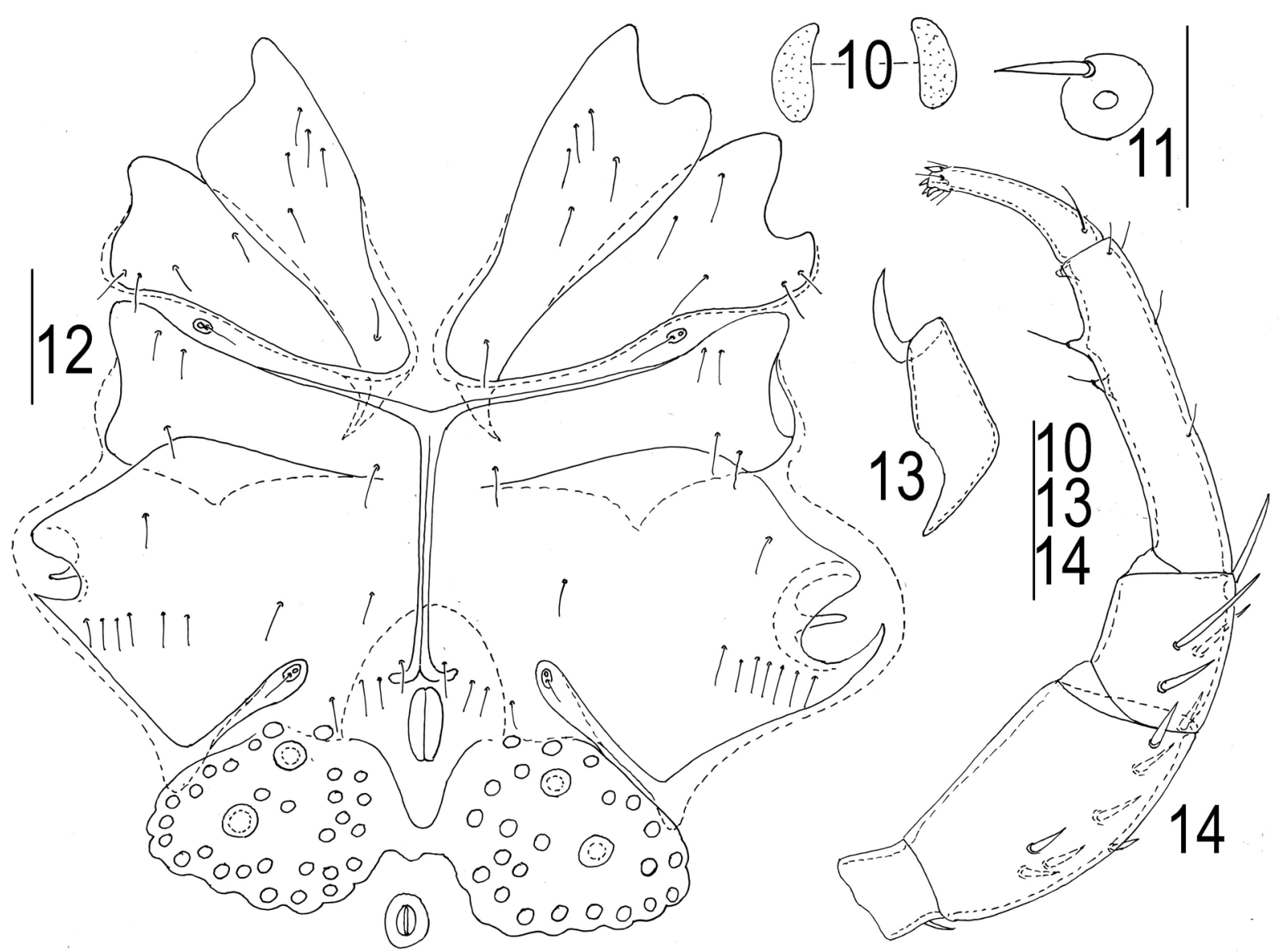

Figs. 10-14. Piona kolymaensis sp.n., male: 10 - dorsal platelets; 11 — seta Fch; 12 -idiosoma, ventral view; 13 chelicera; 14 - pedipalp, lateral view. Scale bars: $10,13,14$ and $12=200 \mu \mathrm{m}, 11=50 \mu \mathrm{m}$.

approximately equal in length, but setae $F c h$ (Fig. 11) thicker than other idiosomal setae. Anterior coxal groups separated with short apodemes (Fig. 12). Sclerites bearing setae $H v$ free. Posterior coxal groups touching, but not fused medially. Suture line between third and fourth coxal plates incomplete, obliterated medially on each side. Acetabular plates fused to coxal plates IV posterior margin and slightly extending laterally beyond posterior projections of these plates. Gonopore longer than wide, oval with nearly parallel lateral margin, genital pit deep, 22-30 genital acetabula on each side. Excretory pore surrounded by narrow sclerotized ring and situated anteriorly to setae $\mathrm{Pi}$ and $\mathrm{Ci}$.

Chelicera (Fig.13) with large basal segment and short crescent chela. Pedipalp (Fig. 14) slender: P-1 short, with single short dorsodistal seta; P-2 ventral margin straight, with eight short subequal dorsal setae; P-3 short, with four unequal setae shorter than dorsal margin of segment; P-4 longer than P-2, in whole length equal thickness, with two distinct unequal ventral setal tubercles lying behind each other distally to middle of segment (distal setal tu- bercle a little large than proximal one), ventrodistal peg-like seta short and directed ventrally; P-5 relatively long, curved with proximal solenidion, five thin setae and four very short, thick distal spines.

Ejaculatory complex (Fig. 15) proximal chamber large, with a curving narrow proximal projection forming single coil, proximal and distal arms subequal in length.

I/II-Leg-6 hardly thickened distally (Fig. 16), I/II-Leg-5 narrowed distally; III-Leg-5 very long (III-Leg-5/III-Leg-6 L ratio 2.1-2.5) and subequal thickness along entire length, III-Leg-6 short and weakly curved, of subequal thickness along entire length, its dorsal margin convex, ventral margin concave (Fig. 17); IV-Leg-4 comparatively thick, with a concavity bearing numerous unequal spinelike setae, IV-Leg-5 straight subequal thickness along entire length and longer than IV-Leg-4 and IV-Leg-6, thin straight, with five long thick setae (Fig. 18). Number of swimming setae as follows: one on I-Leg-4, two to five on I-Leg-5, four to five on II-Leg-4, five to seven on II-Leg-5, six to ten on III-Leg-5, three on IV-Leg-4, six to eight on 


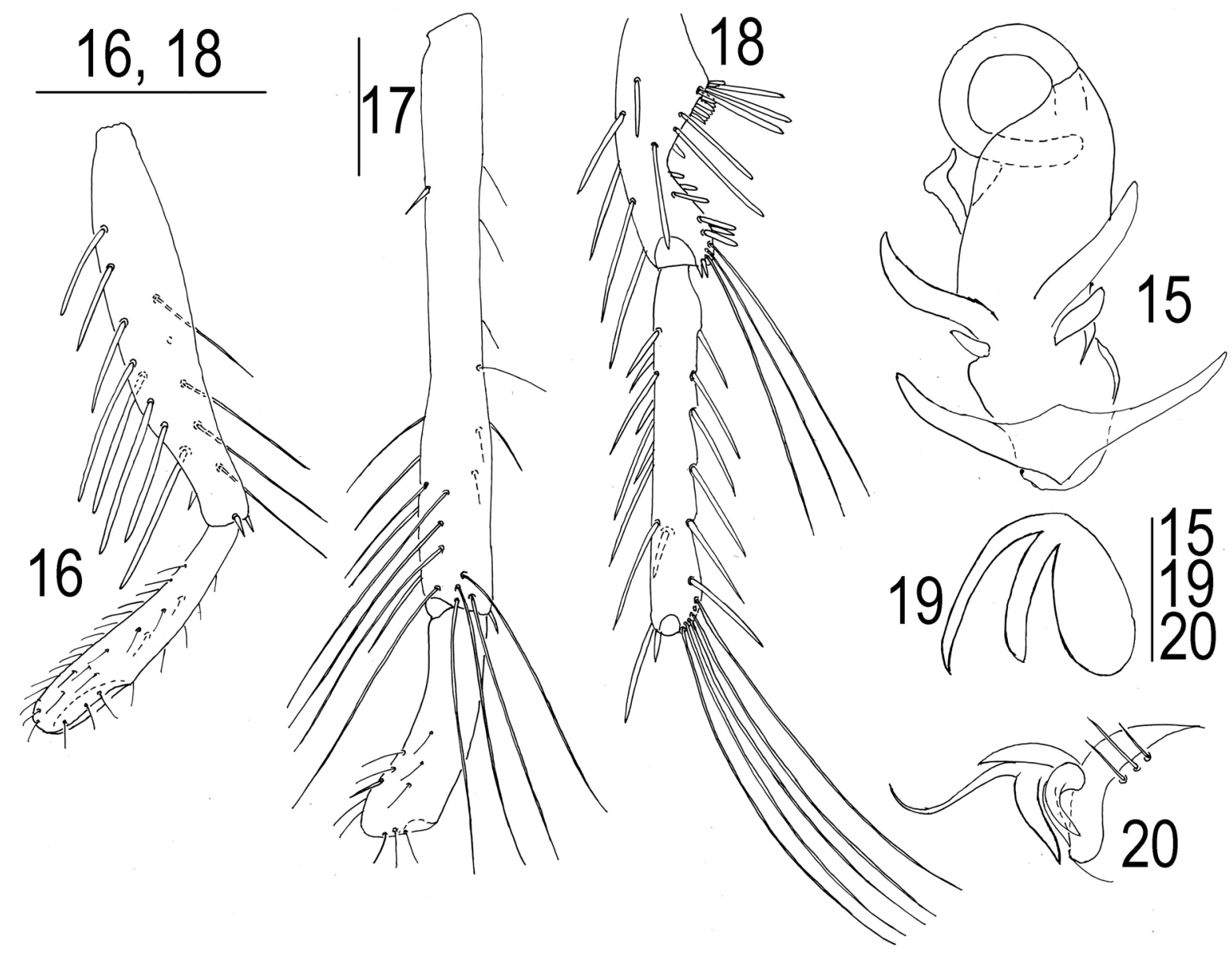

Figs. 15-20. Piona kolymaensis sp.n., male: 15-ejaculatory complex; 16-I-Leg-5-6; 17-III-Leg-5-6; 18-IVLeg-4-5; 19 — claw of leg I; 20 — claws of leg III. Scale bars: 15, 19, 20=50 $\mu \mathrm{m}, 16,18$ and $17=100 \mu \mathrm{m}$.

IV-Leg-5. Claws of tarsi I-II relatively large, with long external clawlet and relatively short internal one (Fig. 19). Claws of legs III asymmetric (Fig. 20), large claw with long dorsal clawlet. Its distal part bent at an angle $90^{\circ}$ and a relatively short, thick pointed slightly curved ventral clawlet. Small claw with two pointed subequal clawlets.

Measurements $(\mathrm{n}=3)$. Idiosoma L 980-1,275; seta Fch L 20-30; genital field W 435-535; cheliceral segments L: base 225-350, chela 105-139; pedipalp segments (P-1-5) L: 80-90, 250-325, 135-175, 310-375, 135-180; leg segments L: I-Leg-1-6: 95-130, 170-270, 195-235, 275-345, 375-450, 270-335; II-Leg-1-6: 95-130, 220-260, 200-245, 310-370, 400-465, 275-320; IIILeg-1-6: 90-115,195-260, 145-180, 270-325, 400-450, 180-195; IV-Leg-1-6: 185-220, 185-235, 160-205, 285-350, 430-490, 335-390.

Differential diagnosis. The male of $P$. kolymaensis sp.n. is similar to males of Piona coccinea (Koch, 1836), P. stjordalensis (Thor, 1897), P. alpicola (Neuman, 1880) and $P$. simulans Tuzovsky,
2016. The genital pit in males of the latter species trifoliate (Gerecke et al. 2016; Tuzovsky 2016), while in the male of $P$. kolymaensis sp.n. genital pit oval (Fig. 12). P-2 ventral margin in P. stjordalensis and $P$. simulans convex, while $\mathrm{P}-2$ ventral margin in $P$. kolymaensis straight. The male of Piona coccinea's P-2 ventral margin straight, but III-Leg-6 short and bent, strongly expanded distally, one claw short and thick, the other claw shaped as a large, circular, sharp hook (Davids and Kouwets 1987; Gerecke et al. 2016).

Etymology. The species epithet "kolymaensis" is derived from the name of the territory where it was collected (Kolyma River basin).

Habitat. Standing waters.

Distribution. Asia (Russia: Magadan Region).

\section{Piona neococcinoides sp.n.}

Figs. 21-33

Type material. Holotype: male, slide 4446, Asia, Russia, Magadan Region, Chaun District, 


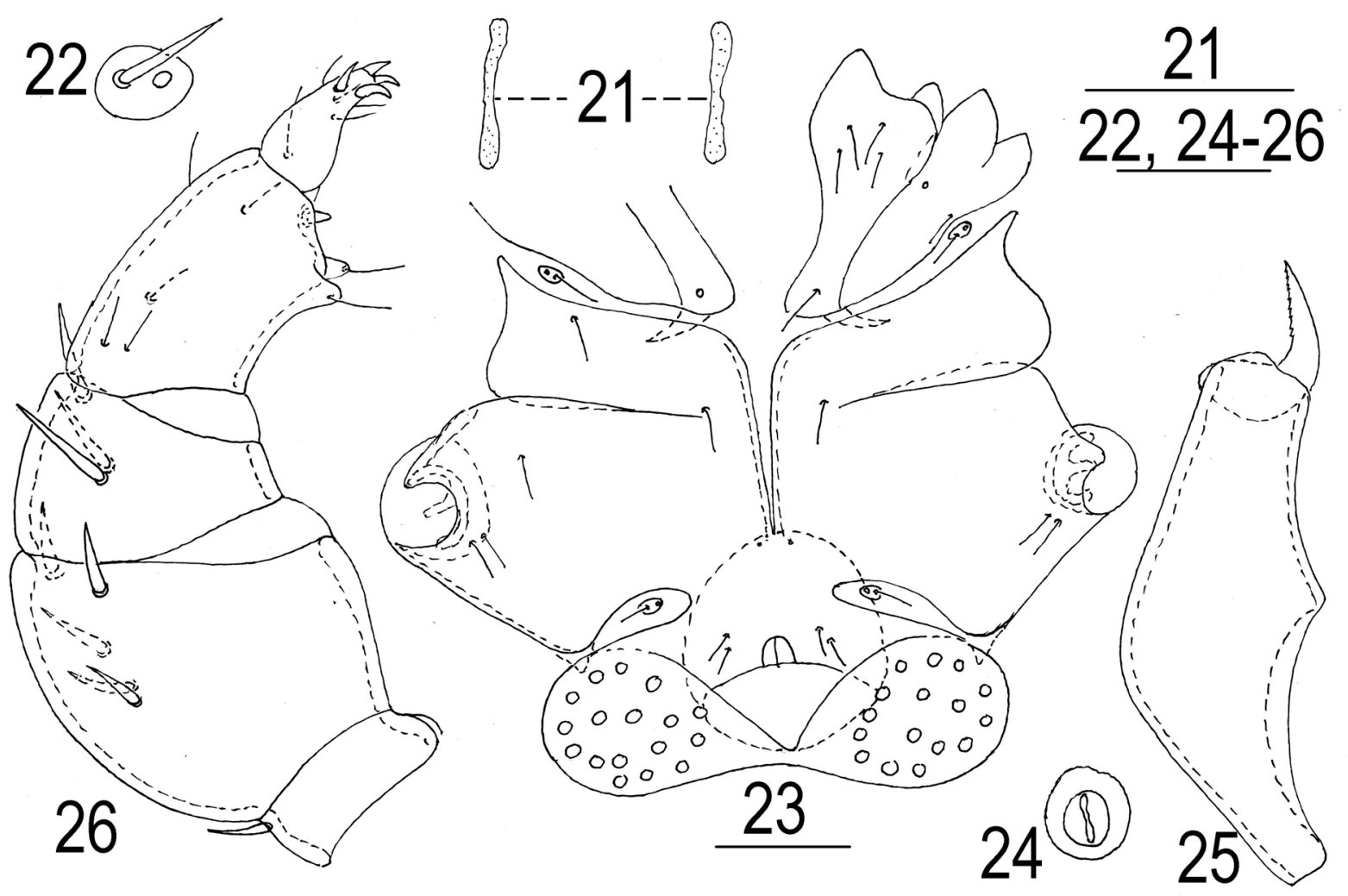

Figs. 21-26. Piona neococcinoides sp.n., male: 21 - dorsal platelets; 22 - seta Fch; 23-idiosoma, ventral view; $24-$ excretory pore; 25 - chelicera; 26-pedipalp. Scale bars: 21 and $23=100 \mu \mathrm{m}, 22,24-26=50 \mu \mathrm{m}$.

small sedge bog on the right bank of the Pucheveem River, $18 \mathrm{~km}$ upstream from the river mouth, 11 July 1982, coll. P.V. Tuzovsky.

Diagnosis. Male: Fch short, thick; pedipalp stocky, thick, P-3 with three short unequal setae these shorter than dorsal margin of segment, lateral seta located near middle of segment, P-4 shorter than P-2 with two distinct setal tubercles, lying close to each outer; posterior coxal group separated anteriorly and touching posteriorly; 17-18 pairs subequal genital acetabula; gonopore wider than long, trapezoidal in shape, genital pit deep, genital field slightly extending laterally beyond posterior projections of coxal plates IV; ejaculatory complex with long proximal arms and short distal arms, proximal chamber large, with a curving narrow proximal projection, forming three coils; I/II-Leg-6 strong thickened distally.

Description. Color red. Idiosoma oval, integument soft and finely striated. The number and position of idiosomal setae typical for the genus Piona. Dorsum with two small elongate narrow platelets (Fig. 21). All dorsal setae thin and approximately equal in length, but setae $F c h$ (Fig. 22) shorter and thicker than other idiosomal setae. Anterior coxal groups separated with short apo- demes (Fig. 23). Sclerites bearing setae and glandularia $H v$ free. Posterior coxal group separated anteriorly and touching posteriorly. Suture line between third and fourth coxal plates incomplete obliterated medially on each side. Acetabular plates fused to coxal plates IV posterior margin and slightly extending laterally beyond posterior projections of these plates. Gonopore wider than long, trapezoidal in shape with small median incision anteriorly, genital pit deep, 17-18 genital acetabula on each side. Excretory pore surrounded by narrow sclerotized ring and situated anteriorly to setae $P i$ and $C i$. Ejaculatory complex with proximal arms larger than distal arms, proximal chamber large, with a curving narrow proximal projection, forming three coils.

Chelicera (Fig. 25) with large basal segment and short crescent chela. Pedipalp (Fig. 26) stocky: P-1 short, with single short dorsodistal seta; P-2 ventral margin slightly convex, with five short subequal dorsal setae; P-3 short, with three short unequal setae these much shorter than dorsal margin of segment; P-4 shorter than P-2, with ventral protrusion bearing two distinct setal tubercles, lying close each other distally to middle of segment, distal peg-like seta directed ventrally; P-5 with 


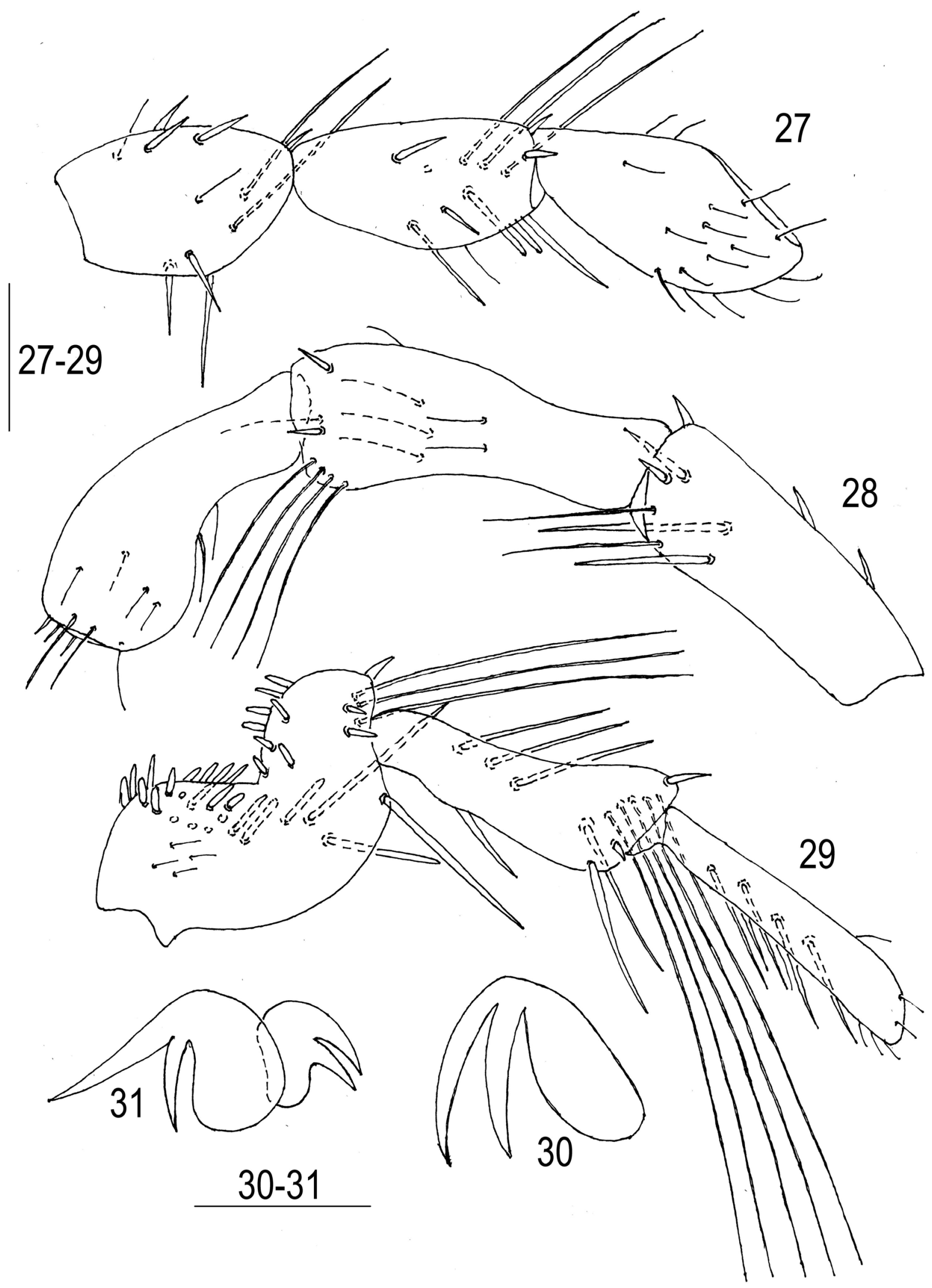

Figs. 27-31. Piona neococcinoides sp.n., male: 27-I-Leg-4-6; 28-III-Leg-4-6; 29-IV-Leg-4-6; 30—claw of leg I; 31 - claws of leg III. Scale bars: $27-29=100 \mu \mathrm{m}, 30-31=50 \mu \mathrm{m}$. 

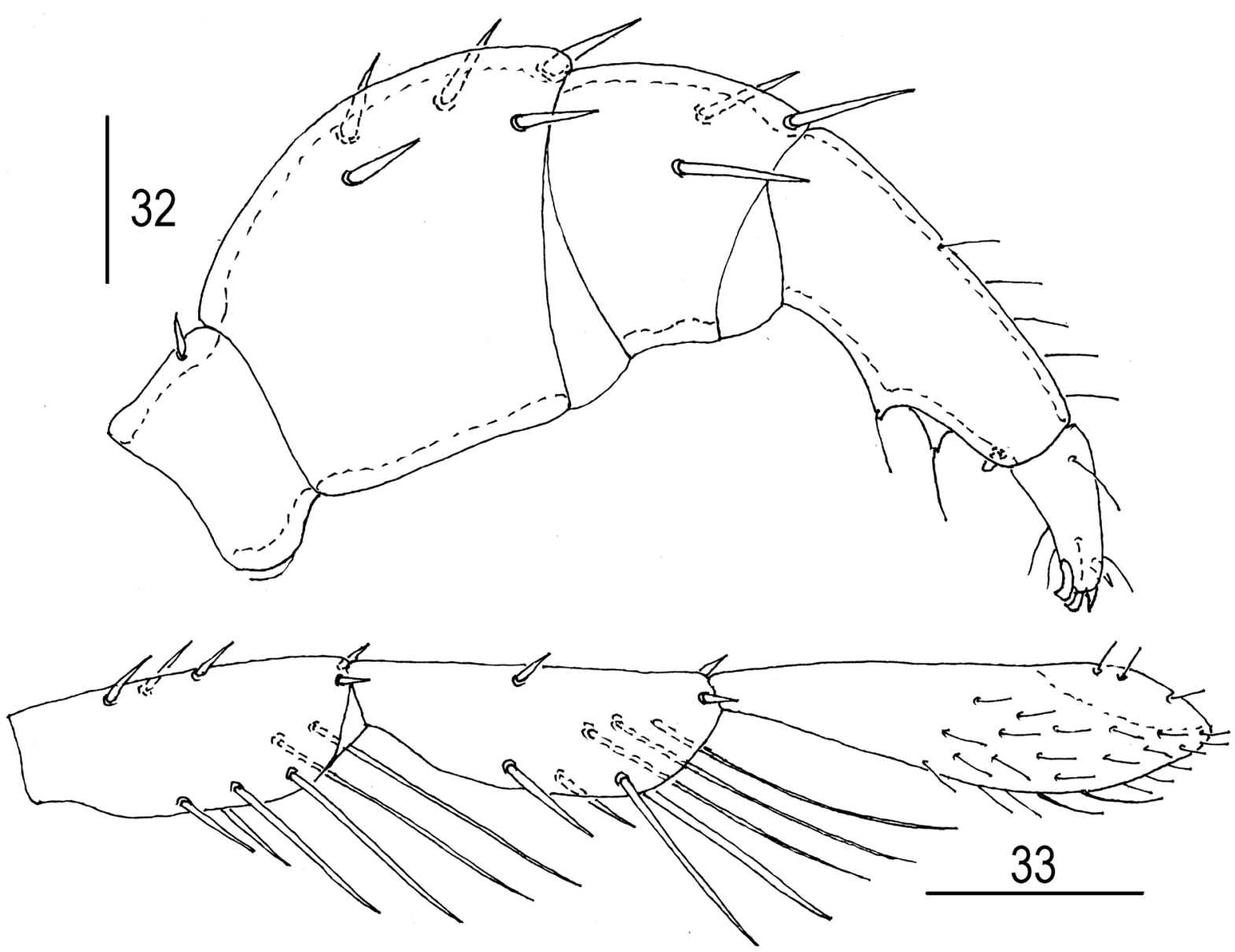

Figs. 32-33. Piona coccinoides (Thor, 1897), male: 32 - pedipalp, 33-I-Leg-4-6. Scale bars: 32=50 $\mu \mathrm{m}, 33=100 \mu \mathrm{m}$.

proximal solenidion, four thin setae and four very short, thick distal spines.

Legs comparatively short: I/II-Leg-6 strong thickened distally (Fig. 27); III-Leg-5 slightly expanded distally, III-Leg-6 comparatively short and club-shaped (Fig. 28); IV-Leg-4 thick, with a deep concavity bearing numerous unequal spinelike setae, IV-Leg-5 narrowed in anterior half and expanded distally, IV-Leg- 6 thin straight, with one short and four long thick setae (Fig. 29). I-Leg-4 with two, I-Leg-5 with three short swimming setae. Legs II-IV with long swimming setae, their number as follows: three on II-Leg-4 and IVLeg-4, three to four on II-Leg-5; four on III-Leg-5, five to six on IV-Leg-5. Claws of tarsi I-II relatively large, with two subequal pointed clawlets (Fig. 30). Claws of legs III asymmetrical (Fig. 31 ); large claw with thick, long straight dorsal clawlet and a relatively short, thin slightly curved ventral clawlet. Small claw with two thick pointed subequal clawlets.

Measurements $(\mathrm{n}=1)$. Idiosoma L 660; seta Fch L 25-35; genital field W 325; cheliceral segments
L: base 185 , chela 62 ; pedipalp segments $(\mathrm{P}-1-5)$ L: 37, 125, 70, 112, 50; leg segments L: I-Leg-1-6: 70, 85, 95, 125, 125, 150; II-Leg-1-6: 75, 85, 95, 125, 135, 170; III-Leg-1-6: 75, 125, 112, 180, 200, 162; IV-Leg-1-6: 120, 95, 100, 180, 170, 155.

Differential diagnosis. While the male of the new species is similar to Piona coccinoides (Thor, 1897), the two differ by the structure of the pedipalp and the legs. The comparison is given using the males collected in the Magadan Region of Russia. $\mathrm{P}-2$ ventral margin in the male of $P$. coccinoides straight (Fig. 32), P-4 rather slender with nearly straight ventral margin, I/II-Leg-6 comparatively slightly thickened (Fig. 33). In contrast, in the male of $P$. neococcinoides sp.n. P-2 ventral margin convex, P-4 thick, with distinct protrusion distally to middle of segment (Fig. 26), I/II-Leg-6 strongly thickened (Fig. 27).

Etymology. The species epithet, neococcinoides, is derived from the name of Piona coccinoides.

Habitat. Small temporary standing waters.

Distribution. Asia (Russia: Magadan Region). 


\section{ACKNOWLEDGEMENTS}

This research was performed in the framework of the state assignment by FASO, Russia (currently included into the Ministry of Science and Higher Education of Russia), theme No 0122-2014-0007. The author expresses sincere gratitude to anonymous referees for reviewing the manuscript.

\section{REFERENCES}

Davids, C. and Kouwets, F.A.C. 1987. The characteristics of some water mite species of the genus Piona (Acari, Hydrachnellae) with three new larval descriptions. Archiv für Hydrobiologie, 110 (1): 1-18.

Gerecke, R., Gledhill, T., Pešić, V. and Smit, H. 2016. 8. Acari: Hydrachnidia III. In: R. Gerecke (Ed.). Süßwasserfauna von Mitteleuropa, 7/2-3. Springer-Verlag, Berlin, Heidelberg, 429 pp.

Tuzovsky, P.V. 1987. Morfologiya i postembrional'noe razvitiye vodyanykh kleshchey [Morphology and
Postembryonic Development in Water Mites]. Nauka, Moscow, 172 pp. [In Russian]

Tuzovsky, P.V. 2005. A new water mite species of the genus Piona Koch from Karelia. Zoosystematica Rossica, 14 (1): 27-29.

Tuzovsky, P.V. 2013. New water mite species of the genus Piona Koch, 1842 (Acari: Hydrachnidia, Pionidae) from Northeastern Russia. Zootaxa, 3664 (3): 321-334.

Tuzovsky, P.V. 2015. A new water mite species of the genus Piona Koch, 1842 (Acari: Hydrachnidia, Pionidae) from Russia. Acarina, 23 (2): 156-160.

Tuzovsky, P.V. 2016. Description of a new water mite species of the genus Piona Koch (Acari, Hydrachnidia, Pionidae) from Northeastern Russia. Acarina, 24 (1): 41-50.

Tuzovsky, P.V. 2017. On the systematics of the water mite Piona nodata (Müller, 1776) (Acari: Hydrachnidia, Pionidae). Acarina, 25 (2): 135-142. 